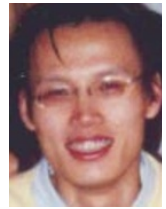

Cell biologists

Married couple jailed pending laboratory theft charges p886

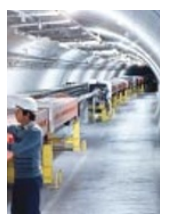

Fast buck

CERN announces cash-saving cutbacks in synchrotron use p888

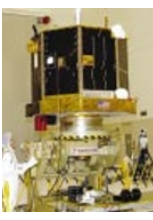

Aiming high

New missions usher in a revival for comet exploration p889

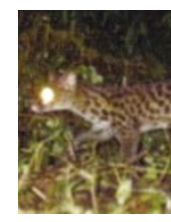

Film star

African predator caught on camera for the first time p890

\title{
Code of conduct for bioethics branded 'soft' on corporate ties
}

Nell Boyce, Washington

Big names in bioethics are falling out over how the burgeoning field should set its own ethical boundaries.

The controversy has been ignited by a report by a task force of ten leading bioethicists which outlines how bioethicists should interact with companies that seek their advice.

The task force was convened by two bioethics societies last year. Its report, in the May/June issue of the Hastings Center Report, suggests ways in which bioethicists can safeguard their independence when doing for-profit consulting. It covers issues such as disclosure, confidentiality contracts and compensation.

But in an accompanying commentary, bioethicists Stuart Youngner of Case Western Reserve University in Cleveland, Ohio, and Robert Arnold of the University of Pittsburgh in Pennsylvania dismiss the guidelines as "a 'how-to' manual for a new guild interested in promoting what it already does". They also say that task-force members have not disclosed their own corporate ties.

The dispute arises as bioethics is coming of age as a profession in the United States. As the field gains influence in the media and in policy-making, industrial companies have begun to engage bioethicists to assess controversial work - and to convince the public that they are taking ethics seriously.

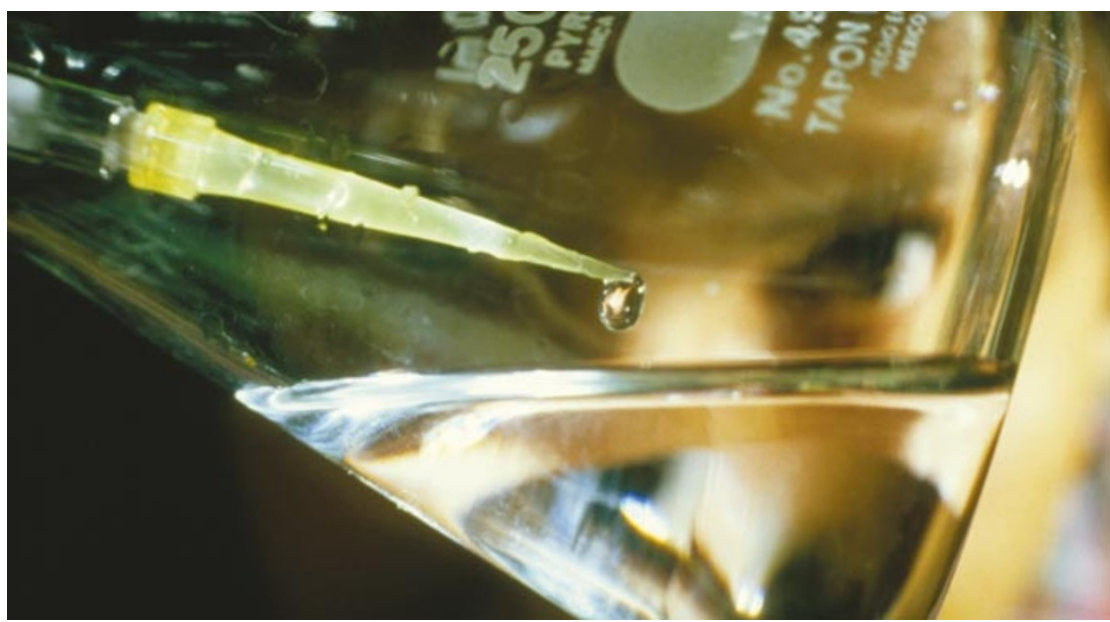

Eyed with suspicion: some bioethicists are concerned by their peers' links with commercial science.

Bioethicists are being offered board positions, consulting contracts, research grants and even stock options. Some of them worry that, as a result, industry is co-opting the field. Others argue that corporate money poses no threat provided that bioethicists declare it and manage corporate relationships with care.

The Hastings Center Report, the journal of the bioethics centre of that name in Garrison, New York, began asking contributors to declare conflicts of interest last year. But the task force's own declaration merely says that eight of the ten authors have "performed consultations of the type described in this article".

That's not good enough, say Youngner and Arnold. Their commentary argues that readers need more information to evaluate the panel's conclusions. To make their point, the two dissidents asked the journal to print exhaustive details of their own income from corporate sources - which it declined to do.

In an editorial, the journal says it doesn't think lengthy disclosures will benefit its readers, as "the facts would lose their punch" and

\section{Bush's advisers lean towards ban on research cloning}

\section{Erika Check, Washington}

The President's Council on Bioethics, which advises US President George W. Bush on thorny issues in medicine and biology, is edging towards recommending a moratorium on cloning human embryos for research.

At its meeting in Washington DC on 20 June, all of the council's members supported a ban on cloning to produce a human baby. But they were divided on 'therapeutic' cloning, which would create embryonic cells in order to study the early stages of human development. The majority of the council supports a moratorium of two to six years on research cloning, but a few of its 18 members - including some scientists have voiced opposition to such a move.

The council's chairman, philosopher Leon Kass of the University of Chicago, says that the panel's report, expected to be published this summer, will probably include a majority verdict and some dissenting views. "When he made his decision on stem cells, the president got as much information as he could," Kass says. "I don't think we'll do him a service if we don't make as strong a case as possible for the different sides" of the debate.

While the Senate has turned its attention away from the cloning issue, Sam Brownback (Republican, Kansas), who leads opposition there to therapeutic cloning, has vowed not to let the issue die (see Nature 417, 775; 2002). Supporters of a moratorium say that backing from the bioethics council could help them garner the support they need.

Gene Tarne, a spokesman for a coalition of anti-cloning groups, says that most opponents of therapeutic cloning had not expected a firm recommendation from the council. If it backs a moratorium, he says, that could sway some senators to vote for it. www.bioethics.gov 


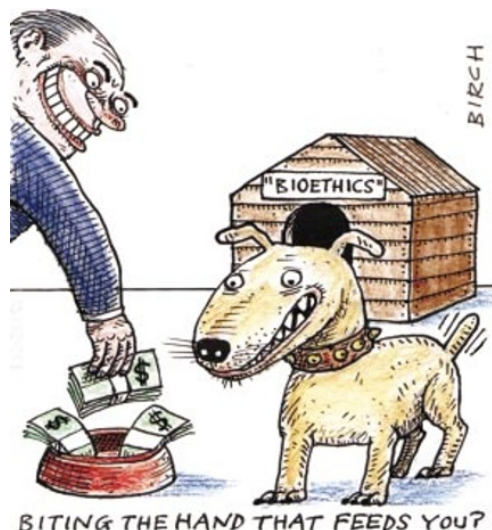

"authors would use the space to subtly spin those facts and forestall readers' concerns".

The co-chairman of the task force, Baruch Brody of Baylor College of Medicine in Houston, Texas, notes that science journals' disclosure statements never include sums of money. He also doesn't see the need for the task-force members to name companies with which they are associated in this case, because no firm stands to benefit from their published opinions.

"The purpose of disclosure is to put people on notice that there's the potential for bias. We've done that," says Brody. But he admits that confidentiality agreements stop him revealing some of his corporate relationships. He says he avoids potential conflict by never publicly discussing bioethics issues relating to those companies.

Such agreements worry Arnold because they rely on the bioethicist to assess where a conflict might arise. "I was saddened by the fact that the committee took a very soft position on secrecy agreements," he says.

Arnold is also worried about problems posed by companies sponsoring academic centres. The Center for Bioethics at the

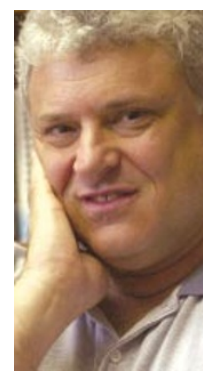

Arthur Caplan: declares funding.
University of Pennsylvania School of Medicine, directed by task-force member Arthur Caplan, for example, has taken funding from companies such as Celera Genomics of Rockville, Maryland, and Monsanto of St Louis, Missouri.

But Virginia Sharpe of the Center for Science in the Public Interest, a pressure group based in Washington DC, says that Caplan's is the only centre of 89 she surveyed that posts funding information on its website.

The bioethics societies have yet to act on the task force's findings, which have split their community. "This has been the most divisive issue in the field as long as I've been in it," says task-force member Jeffrey Kahn of the University of Minnesota.

www.thehastingscenter.org

\section{Scientists jailed for alleged theft from Harvard laboratory}

\section{Rex Dalton, San Diego}

A married couple have been arrested and imprisoned in San Diego pending trial for their alleged theft of genetic material from Harvard University for shipment to an unnamed drug company in Japan.

Federal investigators say the couple stole genetic clones, reagents and records relating to immunosuppressive drug development from a Harvard molecular biology laboratory where they both worked in 1999.

Supporters of the pair in San Diego say that, although the couple made "stupid" mistakes at Harvard, they are being treated excessively harshly for doing what postdoctoral fellows often do.

The two researchers - Jiangyu "Jonathan" Zhu, a Chinese citizen, and his wife, Kayoko Kimbara, a citizen of Japan - or their attorneys could not be reached for comment on the case. The couple, who were arrested on 19 June, are seeking release on bail, but the US Attorney's office wants them to be detained and taken to Boston for trial.

After a two-year investigation by the Federal Bureau of Investigation (FBI), federal prosecutors issued a criminal complaint on 17 June, charging the pair with theft of trade secrets, interstate transportation of stolen property and conspiracy. These felony charges carry a maximum prison term of ten years and fines of up to $\$ 250,000$ each.

Zhu's and Kimbara's arrest is at least the third case of Asian biologists working in the United States being jailed pending theft charges in the past year (see Nature 411, 225-226; 2001 and 417, 576; 2002). But the cases were each handled by different lawenforcement agencies and so do not seem to be a part of an organized crackdown.

The couple met when they were postdocs in the Harvard Medical School laboratory of cell biologist Frank McKeon, who studies genetic control of the immune system. They allegedly stole materials and data relating to the genetic regulation of calcineurin, a signalling protein in the heart, brain and immune system.

An FBI affidavit claims that the pair switched to night shifts, worked without supervision and discovered potentially new immune-system genes, which were not disclosed to McKeon. After falling out with McKeon in 1999, the affidavit says that they moved in January 2000 to the University of Texas Health Science Center in San Antonio, where Zhu was made an assistant professor with Kimbara as his postdoc.

The pair removed more than 30 boxes of

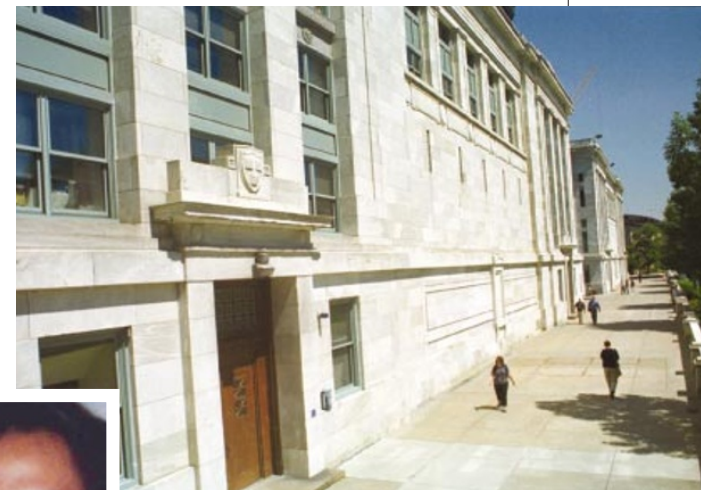

Jiangyu Zhu (left) faces up to ten years in prison for allegedly stealing from Frank McKeon's Harvard lab.

materials from McKeon's lab late at night, at the end of 1999, according to the affidavit. In early 2000 , it claims, Harvard officials went to San Antonio, where they searched Zhu's lab, locating and repossessing Harvard material that they valued at $\$ 300,000$. Texas officials then declined to renew Zhu's contract, prompting him and his wife to leave that summer.

Unable to secure a research position, Zhu contacted Jean Wang, a molecular biologist at the University of California, San Diego (UCSD), who says she decided to give him "a second chance" in January 2001.

While Zhu began a new line of research on apoptosis in thyroid cancer cells in Wang's laboratory, Kimbara took up a postdoctoral position at the Scripps Research Institute in La Jolla, working in the vascular-biology lab of Mark Ginsberg.

Wang, who consulted McKeon before hiring Zhu, feels that a double standard is being applied to the couple, as postdocs often take reagents and records when they leave a laboratory. "It is horrible," says Wang of the prosecution. "It is like a goliath crushing an ant."

Wang acknowledges, however, that she wasn't aware of the alleged transfer of research material to Japan until this May. After she learned of the FBI inquiry into a transfer, Wang says Zhu told her he sent plasmids to a former McKeon postdoc who had returned to his native Japan. This was described as an innocent scientific exchange to create antibodies, Wang recalls.

But federal records allege that e-mails show that the material was destined for commercial use for a possible drug to block organ rejection. The Japanese company which has not been named - is cooperating with the US authorities and has returned the Harvard material. 